\title{
Pengembangan Bahan Ajar Flip Book Kontekstual Berbasis Android Pada Materi Akuntansi Persediaan
}

\author{
Gifar Fahrezi*1, Susanti ${ }^{2}$ \\ gifar.17080304054@mhs.unesa.ac.id,susanti@unesa.ac.id \\ ${ }^{1,2}$ Program Studi Pendidikan Akuntansi, Fakultas Ekonomika dan Bisnis, Universitas Negeri Surabaya \\ Received: Mei 2020 \\ Accepted: Juni 2021 \\ Online Published: Juli 2021
}

\begin{abstract}
This development research aims to create teaching materials in a contextual flipbook on financial accounting subjects, especially Android-based inventory accounting materials for Vocational High School class XI for competency in institutional accounting and financial expertise. The development of this flipbook was tested by material experts, language experts, and graphic experts and tested on 20 participants, namely students from class XI accounting and financial institutions at SMKN 1 Geger Kab. Madiun. The development research model used is $4 D$ by Thiagarajan, which consists of the define, design, develop stages without the dissemination stage. The analysis technique used in this research is descriptive qualitative, and quantitative. The results of the validity analysis obtained the material feasibility of $85,2 \%$, language feasibility of $94,3 \%$ and graphics of $87,1 \%$, with an average result of expert validation of $88,87 \%$ with the predicate very feasible. The average result of student responses is $95,6 \%$, with the very good category. So that the inventory accounting teaching materials developed with a contextual approach are very suitable for use in learning activities.
\end{abstract}

Keywords: Contextual, Flipbook, Teaching Materials, Inventory Accounting

\begin{abstract}
Abstrak
Penelitian pengembangan ini bertujuan untuk menciptakan bahan ajar berbentuk Flip book kontekstual pada mata pelajaran akuntansi keuangan terutama materi akuntansi persediaan berbasis android untuk Sekolah Menengah Kejuruan kelas XI kompetensi keahlian akuntansi dan keuangan lembaga. Pengembangan Flip book ini diuji oleh ahli materi, ahli bahasa, serta ahli grafis, dan diuji cobakan kepada 20 partisipan yakni siswa dari kelas XI akuntansi dan keuangan lembaga di SMKN 1 Geger Kab. Madiun. Model riset pengembangan yang digunakan yakni $4 D$ oleh Thiagarajan yang terdiri dari tahap define, design, develop tanpa tahap disseminate. Teknik analisis yang digunakan dalam penelitian ini ialah deskriptif kualitatif dan kuantitatif. Hasil analisis validitas didapatkan kelayakan materi sebesar 85,2\%, kelayakan bahasa sebesar $94,3 \%$ serta grafis sebesar $87,1 \%$ dengan hasil rerata validasi ahli sebesar $88,87 \%$ dengan predikat sangat layak. Hasil rerata respon siswa sebesar 95,6\% dengan kategori sangat baik. Sehingga bahan ajar akuntansi persediaan yang dikembangkan dengan pendekatan kontekstual sangat layak untuk digunakan dalam kegiatan pembelajaran.
\end{abstract}

Kata kunci: Akuntansi Persediaan, Bahan Ajar, Flip book, Kontekstual 


\section{PENDAHULUAN}

Perkembangan ilmu pengetahuan dan teknologi yang pesat, membuat dunia pendidikan terus menyesuaikan dan menyelaraskan berbagai aspek dengan perubahan maupun kecanggihan teknologi untuk meningkatkan kualitas pendidikan yang lebih baik. Kontribusi akan kecanggihan teknologi saat ini juga digunakan sebagai alat untuk mendesain pembelajaran (Asrowi et al., 2019). Saat ini kurikulum Indonesia telah mengadopsi Kurikulum 2013 Revisi sebagai kurikulum lembaga pendidikan termasuk sekolah menengah kejuruan yang berlaku secara nasional. Dalam mengimplementasikan pembelajaran kurikulum 2013 perlu beradaptasi dan menggunakan teknologi informasi dan komunikasi (Prasetyo, 2018).

Salah satu penerapan dari teknologi pada pembelajaran kurikulum 2013 adalah penggunaan sumber belajar seperti bahan ajar. Bahan ajar ialah sumber kajian yang digunakan pada aktivitas pembelajaran. Sebagai sumber belajar bahan ajar menghadirkan semua komponen yang dirancang dari sistem pengajaran sehingga dapat digunakan dan memberikan manfaat dalam kegiatan pembelajaran (Prastowo, 2018). Bahan ajar atau buku teks pelajaran merupakan sumber pembelajaran utama untuk mencapai kompetensi dasar maupun kompetensi inti dan dinyatakan layak digunakan pada satuan pendidikan oleh Kementerian Pendidikan dan Kebudayaan (Permendikbud, 2016). Oleh sebab itu bahan ajar yang dimanfaatkan pada aktivitas pembelajaran sebaiknya dirancang oleh guru sesuai dengan kebutuhan yang berpedoman pada kompetensi dasar dan kompetensi inti beserta capaian indikator sebagai tujuan dari aktivitas pembelajaran.

Bahan ajar pendekatan kontekstual merupakan bahan ajar dengan proses perumusan yang memberikan contoh-contoh berdasarkan apa yang terjadi atau keadaan yang sebenarnya, sehingga dapat mengkaitkan isi pembelajaran dengan studi kasus sesuai situasi di lingkungan siswa (Rahmawati \& Susanti, 2019). Bahan ajar kontekstual dapat memberikan dampak yakni siswa akan lebih cepat dan mudah dalam pemahaman materi karena adanya contoh-contoh yang disesuaikan dengan kehidupan lingkungan sekitar maupun kegiatan sehari-hari, sehingga mereka lebih mengerti dan tanggap. Menurut (Böhm \& Constantine, 2016) Pembelajaran kontekstual yang memanfaatkan teknologi dapat dikategorikan sebagai bentuk pembelajaran elektronik lanjutan dari e-learning. Sehingga pembelajaran kontekstual dengan menggunakan teknologi android merupakan salah satu bentuk kemajuan dari pembelajaran elektronik.

Flip book berbasis android merupakan buku digital yang berformat seperti layaknya buku yang bisa di bolak-balik dalam tampilan virtual pada smartphone android. Menurut (Besthari, 2017) pemanfaatan teknologi sebaiknya adalah sesuatu yang dimiliki oleh mayoritas siswa. Mempertimbangkan kecenderungan siswa dalam penggunaan perangkat seluler, guru harus 


\section{Educatio: Jurnal IImu Kependidikan}

Vol. 16, NNo 1 Juli 2021, hal. 58-70

http://e-journal.hamzanwadi.ac.id/index.php/edc

e-ISSN: 2527-9998 DOI: 10.29408/edc.v16i1.3550

mengintegrasikan teknologi ke dalam pembelajaran untuk memfasilitasi proses akademik (Sakibayev et al., 2019). Kebanyakan siswa mempunyai smartphone, oleh sebab itu pembuatan bahan ajar berbasis android sangat tepat dan sesuai. Sehingga siswa dan guru dapat dengan mudah untuk mengakses bahan ajar ini. Bahan ajar flip book akan menyajikan kegiatan pembelajaran yang menarik dan disukai oleh siswa dengan tampilan seperti buku nyata, tidak hanya seperti bahan ajar $e$-book biasa yang hanya berformat pdf saja namun juga dilengkapi teks, gambar, video maupun audio. Hal ini akan memperkaya konten dan membuat lebih menarik dengan merangsang siswa untuk menerima pengetahuan (Sung et al., 2019). Sehingga siswa tidak merasa jenuh atau bosan saat menggunakan bahan ajar flip book ini. Bahan ajar akan membantu siswa untuk dapat mengulang meteri pembelajaran jika belum jelas (Logan et al., 2020). Sehingga bahan ajar akan memberikan kesempatan belajar mandiri bagi siswa.

Diperoleh fakta berdasarkan hasil wawancara bahwa saat ini belum tersedia bahan ajar khususnya untuk materi persediaan pada mata pelajaran akuntansi keuangan bagi siswa, baik berupa buku teks maupun bahan ajar lainnya sehingga proses pembelajaran hanya dengan menggunakan buku pegangan guru dan secara manual maupun online guru memberikan hand out materi kepada siswa secara bertahap. Kegiatan pembelajaran saat ini menerapkan pembelajaran daring (online) karena adanya virus covid-19 membuat banyak siswa kesulitan dalam memahami materi akuntansi persediaan karena berkaitan dengan banyak konsep yang harus dijelaskan dengan contoh kasus dan memuat banyak tahapan, pencatatan maupun perhitungan. Sehingga pentingnya pembuatan bahan ajar flip book berbasis android untuk materi ini cocok dan tepat menggunakan pendekatan kontekstual yang menyelaraskan materi dengan kehidupan maupun kegiatan sehari-hari dan menambahkan video tutorial perhitungan.

Kajian empiris penelitan terdahulu yang dilakukan oleh (Ningsih \& Hakim, 2020), dengan hasil buku kontekstual pada mata pelajaran layanan lembaga keuangan syariah dengan interpretasi sangat layak digunakan dengan memperoleh nilai rata-rata 96,05\% untuk validitas kelayakan materi, bahasa dan grafis serta skor rata-rata 95,18\% dari hasil respon siswa. Penelitian lain yang relevan dilakukan oleh (Nurfita \& Susanti, 2018) bahwa bahan ajar meraih predikat sangat layak berdasarkan hasil validasi dari semua ahli terkait kelayakan materi, bahasa, dan grafis serta didapatkan hasil respon peserta didik tentang bahan ajar dengan kriteria sangat memahami. Penelitian serupa juga dilakukan (Andani \& Yulian, 2018) bahwa bahan ajar electronic berbasis flip book yang dikembangkan memperoleh dampak positif dalam peningkatkan hasil belajar bagi peserta didik. Selaras dengan penelitian (Fitryani \& Hunaepi, 2016) bahwa modul elektronik berbasis smartphone android yang telah dikembangkan mendapatkan hasil interpretasi baik dan dinyatakan layak untuk digunakan pada kegiatan pembelajaran.

Tujuan dari penelitian pengembangan ini yakni untuk menganalisis proses pengembangan bahan ajar flip book kontekstual berbasis android materi akuntansi persediaan kelas xi smk akuntansi keuangan lembaga, menganalisis kelayakan bahan ajar flip book 


\section{Educatio: Jurnal IImu Kependidikan}

Vol. 16, NNo 1 Juli 2021, hal. 58-70

http://e-journal.hamzanwadi.ac.id/index.php/edc

e-ISSN: 2527-9998

DOI: 10.29408/edc.v16i1.3550

kontekstual berbasis android, serta menganalisis respon siswa kelas xi smk akuntansi keuangan lembaga terhadap bahan ajar flip book kontekstual. Bahan ajar flip book kontekstual berbasis andorid pada penelitian ini memiliki spesifikasi kelebihan dikembangkan dengan pendekatan kontekstual, bisa dibuka di smartphone android secara offline, memiliki tampilan seperti buku nyata dalam bentuk virtual book, mengacu pada kompetensi dasar yang berlaku serta terdapat video tutorial perhitungan di dalamnya dan mengarah pada ranah $\mathrm{C} 3$ atau penerapan materi secara langsung dengan contoh kasus. Sehingga dapat membantu siswa lebih mudah memahami materi akuntansi persediaan.

\section{METODE PENELITIAN}

Penelitian ini akan menerapkan model penelitian 4D oleh Thiagarajan, Semmel, dan Semmel research and development (R\&D) yang terdiri dari 4 tahap, namun pada penelitian ini hanya melaksanakan tahap pendefinisian (define), perancangan (design) dan pengembangan (develop). Tahap penyebaran (desseminate) tidak dilaksanakan dengan alasan keterbatasan kemampuan peneliti dalam melakukan diseminasi). Menurut (Sugiyono, 2018) Penelitian dan pengembangan merupakan jenis riset yang dipergunakan dalam menciptakan produk serta mengukur tingkat kelayakan produk.

Penelitian ini pada tahap validasi ahli melibatkan dua ahli materi, satu ahli bahasa dan satu ahli grafis. Ahli materi yakni dosen prodi S1 Pendidikan Akuntansi, dan guru pengampu mata pelajaran akuntansi keuangan kelas xi yang mempunyai keahlian dalam bidang khususnya akuntansi persediaan. Ahli bahasa yakni dosen prodi S1 Pendidikan Bahasa dan Sastra Indonesia, yang mempunyai keahlian pada bidang bahasa indonesia. Ahli grafis dari dosen prodi S1 Teknologi Pendidikan, yang mempunyai keahlian dalam bidang grafis. Semua dosen tersebut merupakan pengajar di Universitas Negeri Surabaya. Subjek pada penelitian ini adalah 20 siswa Kelas XI Akuntansi Keuangan Lembaga SMKN 1 Geger Kab.Madiun. Pemilihan 20 siswa yang menjadi subjek uji coba penelitian ini dipilih berdasarkan kemampuan kognitif yang bervariasi hasil rekomendasi guru pengampu.

Data pada penelitian pengembangan ini terdiri dari data kualitatif dan data kuantitatif. Data kualitatif dalam penelitian pengembangan didapatkan melalui hasil analisis lembar telaah dari ahli materi, bahasa serta grafis. Data kualitatif ini berbentuk komentar atau saran yang diberikan masing-masing ahli pada lembar telaah terhadap bahan ajar flip book. Sedangkan data kuantitatif pada penelitian pengembangan ini didapatkan melalui analisis dari hasil lembar validasi dari masing-masing ahli berupa lembar penlilaian produk pengembangan. Lembar validasi ahli disajikan dengan menggunakan skala likert. Data kuantitatif juga didapatkan dari analisis dari angket respon siswa dengan penyajian menggunakan skala guttman.

Lembar telaah dan validasi ahli akan ditelaah oleh empat validator ahli. Hasil validasi masing-masing ahli akan dianalisis dalam skala likert sebagai berikut,

\section{Tabel 1. Kriteria Skor Validasi Ahli dengan Skala Likert}




\begin{tabular}{cc}
\hline Kriteria & Skor \\
\hline Sangat layak & 5 \\
Layak & 4 \\
Cukup layak & 3 \\
Tidak layak & 2 \\
Sangat tidak Layak & 1 \\
\hline
\end{tabular}

Sumber: (Riduwan, 2016)

Hasil validasi dari ahli akan dihitung persentasenya dan dianalisis dengan rumus:

$$
\text { Presentase (\%) }=\frac{\text { Jumlah Skor }}{\text { Jumlah Skor Maksimal }} \times 100 \%
$$

Tabel 2. Interpretasi Skor Validasi Ahli dengan Skala Likert

\begin{tabular}{cc}
\hline Presentase & Kriteria Interpretasi \\
\hline $0 \%-20 \%$ & Sangat tidak layak \\
$20 \%-40 \%$ & Tidak layak \\
$40 \%-60 \%$ & Cukup layak \\
$60 \%-80 \%$ & Layak \\
$80 \%-100 \%$ & Sangat layak \\
\hline
\end{tabular}

Sumber: (Riduwan, 2016)

Berdasarkan tabel tersebut apabila seluruh komponen penilaian kelayakan dari masingmasing ahli memperoleh rerata presentase $>61 \%$ maka bahan ajar yang dikembangkan akan memperoleh kriteria interpretasi layak atau sangat layak.

Angket respon siswa akan dianalisis dengan skala Guttman menggunakan kriteria sebagai berikut,

Tabel 3. Kriteria Skor Angket Respon Siswa dengan Skala Guttman

\begin{tabular}{cc}
\hline Kriteria & Skor \\
\hline Ya & 1 \\
Tidak & 0 \\
\hline
\end{tabular}

Sumber: (Riduwan, 2016)

Dari angket respon akan dihitung persentasenya dan dianalisis dengan rumus:

$$
\text { Presentase (\%) }=\frac{\text { Jumlah Skor }}{\text { Jumlah Skor Maksimal }} \times 100 \%
$$

Tabel 4. Interpretasi Skor Angket Respon Siswa dengan Skala Guttman

\begin{tabular}{cc}
\hline Presentase & Kriteria Interpretasi \\
\hline $0 \%-20 \%$ & Sangat tidak baik \\
$20 \%-40 \%$ & Tidak baik \\
$40 \%-60 \%$ & Cukup baik \\
$60 \%-80 \%$ & Baik \\
$80 \%-100 \%$ & Sangat Baik \\
\hline
\end{tabular}




\section{Educatio: Jurnal IImu Kependidikan}

Vol. 16, NNo 1 Juli 2021, hal. 58-7o

http://e-journal.hamzanwadi.ac.id/index.php/edc

e-ISSN: 2527-9998

DOI: 10.29408/edc.v16i1.3550

Berdasarkan tabel tersebut, apabila seluruh komponen penilaian dalam angket respon siswa memperoleh rerata presentase $>61 \%$ maka bahan ajar yang dikembangkan akan memperoleh predikat baik atau sangat baik.

\section{HASIL}

Tahap pertama pada penelitian ini adalah tahap pendefinisian (define). Tahap pendefinisian ini bertujuan untuk mengetahui masalah dalam pembelajaran dengan cara menganalisis 5 kegiatan, yaitu analisis ujung depan, analisis terhadap siswa, analisis terhadap tugas, analisis konsep, dan perumusan tujuan pembelajaran. Setelah dilakukan analisis ujung depan diketahui permasalahan pada mata pelajaran akuntansi keuangan khususnya materi akuntansi persediaan yaitu belum tersedia bahan ajar selaras dan sesuai kompetensi inti maupun kompetensi dasar yang berlaku. Sesuai dengan penelitian (Anisa \& Rohayati, 2019) bahwa bahan ajar yang selaras dengan silabus dan kompetensi dasar belum tersedia.

Selanjutnya dilakukan analisis terhadap siswa. Kemampuan siswa Kelas XI Akuntansi Keuangan Lembaga dalam kegiatan pembelajaran dan berinteraksi sudah baik. Berdasarkan hasil penilaian guru pengampu mata pelajaran akuntansi keuangan perihal akademik siswa didapati bahwa kebanyakan siswa mengalami kesulitan dalam memahami materi khususnya perhitungan dan tahapan pencatatan pada materi akuntansi persediaan, hal ini dikarenakan belum tersedia bahan ajar materi akuntansi persediaan bagi siswa, baik berupa buku teks maupun bahan ajar lainnya. Untuk saat ini dalam proses pembelajaran hanya dengan menggunakan buku pegangan guru, sehingga guru secara manual memberikan hand out maupun materi kepada siswa secara bertahap sehingga kurang efektif. Hasil dari penelitian (Yulaika et al., 2020) bahwa bahan ajar eletronik berbasis flip book yang dikembangkan layak diterapkan dan efektif dalam peningkatan hasil belajar siswa. Diharapkan semangat siswa dalam proses pembelajaran akan meningkat dan bisa menjadi alternatif untuk membantu siswa dalam memahami materi apabila telah tersedia bahan ajar berupa flip book kontekstual berbasis android ini.

Analisis tugas bertujuan untuk merancang materi dan menyusun rangkaian instruksi bagi siswa terkait penyajian pembelajaran sehubungan dengan pendekatan kontekstual yaitu mengkaitkan materi dengan contoh kehidupan maupun kegiatan sehari-hari. Pada bahan ajar yang dikembangkan, materi disajikan menggunakan basis kontekstual dan terdapat video tutorial perhitungan, adanya soal pada setiap bab yang terdiri dari 10 soal pernyataan benar salah, latihan soal berupa uji kompetensi dengan 20 soal pilihan ganda dan 5 soal uraian.

Analisis selanjutnya adalah analisis konsep bertujuan untuk membuat konsep dengan hasil materi pokok yang disajikan ke dalam bahan ajar dan disusun secara sistematis berdasarkan kompetensi dasar yang sesuai dan berlaku pada Kurikulum 2013 Revisi. Materi pokok pada bahan ajar meliputi, ruang lingkup persediaan, sistem pencatatan persediaan, pencatatan jurnal transaksi dan penerapannya berdasarkan sistem pencatatan persediaan, 


\section{Educatio: Jurnal IImu Kependidikan}

Vol. 16, NNo 1 Juli 2021, hal. 58-70

http://e-journal.hamzanwadi.ac.id/index.php/edc

e-ISSN: 2527-9998

DOI: 10.29408/edc.v16i1.3550

metode penilaian persediaan dan penerapannya berdasarkan sistem pencatatan persediaan, perhitungan nilai persediaan sesuai dengan sistem pencatatan persediaan, kartu persediaan, format kartu persediaan, penerapan kartu persediaan sesuai dengan sistem pencatatannya.

Langkah selanjutnya adalah perumusan tujuan pembelajaran. Karena bahan ajar yang digunakan dalam pembelajaran belum sesuai dengan kompetensi inti maupun kompetensi dasar maka tujuan pembelajaran akan diselaraskan dan disesuaikan pada kompetensi inti maupun kompetensi dasar sesuai dengan silabus mata pelajaran akuntansi keuangan khususnya materi persediaan kelas xi semester 2 kurikulum 2013 revisi. Dengan menambahkan latihan soal berbasis HOTS (high order thinking skills), contoh kasus dan video tutorial perhitungan dalam bahan ajar, maka ranah C3 yakni penerapan materi secara langsung dapat dilakukan sehingga tujuan dari aktivitas pembelajaran bisa tercapai.

Tahap kedua yaitu melakukan perancangan (design). Menurut penelitian (Salma \& Susanti, 2021) tahap perancangan ditujukan untuk merencanakan dan menyusun bahan ajar dengan merancang format bahan ajar selaras dengan kebutuhan pembelajaran. Tahap perancangan ini didasarkan pada Standar BSNP tahun 2014 mengenai instrumen penilaian buku teks pelajaran dan akan disesuaikan oleh peneliti. Format awal bahan ajar meliputi bagian pendahuluan, isi, dan bagian penutup. Pada bagian awal pendahuluan bahan ajar berisi sampul depan, halaman judul, kata pengantar, kompetensi inti maupun kompetensi dasar, daftar isi dan petunjuk penggunaan bahan ajar flip book. Pada bagian isi berisi kompetensi dasar, tujuan pembelajaran yang hendak dicapai, peta konsep, kata motivasi, materi, kegiatan, rangkuman materi, soal uji kompetensi. Bagian akhir atau penutup berisi daftar pustaka, profil penulis dan cover belakang. Bahan ajar yang dirancang dengan desain awal akan direalisasikan menjadi desain awal bahan ajar atau disebut draf produk I.

Tahapan ketiga yakni pengembangan (develop). Bahan ajar pada penelitian ini dikembangkan menggunakan software Flip PDF Professional dan Website 2 Apk Builder Pro sehingga menghasilkan bahan ajar berupa flip book yang bisa dibuka dan diakses melalui smartphone android. Penelitian yang dilakukan oleh (Sumaeny \& Susanti, 2018), dilakukan kegiatan telaah oleh ahli dan berdasarkan masukan maupun saran para ahli dilakukan revisi terhadap bahan ajar. Setelah peneliti membuat draf produk I, selanjutnya akan ditelaah oleh para ahli dan diperoleh saran atau masukan mengenai bahan ajar. Setelah proses telaah para ahli selesai, bahan ajar akan direvisi sehingga menjadi draf produk II dan selanjutnya akan dinilai validitas atau kelayakannya oleh para ahli. Setelah pelaksanaan validitas, peneliti akan menganalisis hasil yang telah diperoleh dari para ahli untuk diinterpretasikan sesuai dengan hasil persentase. Pelaksanakaan uji coba dilakukan pada 20 partisipan yakni siswa Kelas XI Akuntansi dan Keuangan Lembaga 3 SMKN 1 Geger. Uji coba dilaksanakan melalui tatap muka dengan mematuhi protokol kesehatan karena adanya virus covid-19. Bahan ajar diberikan kepada siswa melalui google drive yang dapat diakses dengan proses download terebih dahulu 


\section{Educatio: Jurnal IImu Kependidikan}

Vol. 16, NNo 1 Juli 2021, hal. 58-70

http://e-journal.hamzanwadi.ac.id/index.php/edc

e-ISSN: 2527-9998

DOI: 10.29408/edc.v16i1.3550

dan angket respon siswa dibagikan menggunakan google form. Hasil uji coba akan dianalisis dan diinterpretasikan berdasarkan kriteria sesuai dengan hasil persentase yang didapatkan.

Tahap keempat yaitu penyebaran (disseminate). Sama halnya dengan penelitian yang dilakukan (Laili \& Rohayati, 2018) yakni tidak melaksanakan tahapan penyebaran. Penelitian yang sama juga dilakukan oleh (Sriwahyuni et al., 2019) dengan melaksanakan tiga tahapan tanpa tahap penyebaran. Pada penelitian dan pengembangan bahan ajar flip book ini, tahap penyebaran tidak dilaksanakan dengan pertimbangan keterbatasan kemampuan peneliti dalam melakukan diseminasi.

Kelayakan produk berupa bahan ajar flip book kontekstual pada penelitian pengembangan ini didapatkan dari perhitungan hasil penilaian validasi yang dilaksanakan validator ahli materi, bahasa, serta grafis. Berikut hasil keseluruhan validasi ahli terhadap bahan ajar yang telah dikembangkan:

Tabel 5. Tabel Keseluruhan Hasil Validasi Ahli

\begin{tabular}{clcc}
\hline No. & Aspek & Presentase & Kriteria Interpretasi \\
\hline 1 & Rata-rata validasi ahli materi & $85,2 \%$ & Sangat Layak \\
2 & Rata-rata validasi ahli bahasa & $94,3 \%$ & Sangat Layak \\
3 & Rata-rata validasi ahli grafis & $87,1 \%$ & Sangat Layak \\
\hline & Rata-Rata Keseluruhan & $\mathbf{8 8 , 8 7 \%}$ & Sangat Layak \\
& Validasi & & \\
\hline
\end{tabular}

Sumber: diolah peneliti (2021)

Pada tabel tersebut, perolehan rata-rata persentase validasi ahli materi sebesar 85,2\%. Selaras dengan penelitian yang dilaksanakan (Aini \& Susanti, 2019) bahwa bahan ajar yang dikembangkan memperoleh skor validasi materi sebesar $84,28 \%$ dengan interpretasi sangat layak. Penelitian lain juga dilakukan oleh (Andriani et al., 2019) memperoleh validasi ahli materi dengan nilai $88,8 \%$ dengan meraih predikat sangat layak.

Rata-rata presentase validasi ahli bahasa memperoleh skor 94,3\% dengan kriteria interpretasi sangat layak. Hasil ini selaras dengan penelitian yang dilakukan (Fitriyani \& Susanti, 2020) bahwa kelayakan bahasa terhadap bahan ajar yang dikembangkan memperoleh $81,9 \%$ dengan predikat sangat layak. Penelitian dilaksanakan (Putra \& Rochmawati, 2020) juga memperoleh $80 \%$ untuk kelayakan bahasa terhadap bahan ajar yang dikembangkan dengan predikat layak.

Dalam tabel ditunjukkan hasil dari rata-rata presentase validasi ahli grafis mendapat nilai $87,1 \%$ dengan interpretasi sangat layak. Sejalan dengan penelitian (Oktaviana \& Susilowibowo, 2017) bahwa bahan ajar yang dikembangkan memperoleh rerata kelayakan grafis dengan persentase 92,32\% dan mendapat kategori sangat layak. Penelitian lain juga dilakukan oleh (Alawiyah \& Susanti, 2019) memperoleh nilai 82,59\% dengan predikat sangat layak.

Berdasarkan penghitungan rerata keseluruhan validasi diperoleh skor sebesar $88,87 \%$ dengan interpretasi sangat layak. Selaras dengan penelitian (Royani \& Susanti, 2019) bahwa 


\section{Educatio: Jurnal IImu Kependidikan}

Vol. 16, NNo 1 Juli 2021, hal. 58-70

http://e-journal.hamzanwadi.ac.id/index.php/edc

e-ISSN: 2527-9998

DOI: 10.29408/edc.v16i1.3550

buku ajar yang dikembangkan dengan basis kontekstual mendapatkan persentase rata-rata validitas ahli dengan nilai $85,08 \%$ dalam kategori sangat layak. Hasil ini juga sejalan pada penelitian pengembangan yang dilaksanakan (Astuti et al., 2018) bahwa bahan ajar akuntansi keuangan kompetensi dasar persediaan barang dagang yang dikembangkan memperoleh persentase validitas 94,3\% dengan kategori sangat layak. Penelitian oleh (Bhabiet et al., 2018) juga memperoleh skor $90 \%$ yang berarti e-modul berbasis android tersebut termasuk dalam predikat sangat layak dimanfaatkan pada kegiatan pembelajaran.

Uji coba dilaksanakan guna mendapatkan respon dari siswa terhadap bahan ajar. Pelaksanaan uji coba secara terbatas dengan 20 partisipan yakni siswa Kelas XI Akuntansi Keuangan dan Lembaga 3 SMKN 1 Geger Kab.Madiun. Peneliti memberikan bahan ajar dengan google drive serta angket melalui google form yang dapat diisi oleh siswa. Siswa dimohon mengisi angket respon dengan memberikan klik pada jawaban Ya apabila sesuai dengan pernyataan, dan jawaban Tidak apabila tidak sesuai dengan pernyataan. Berikut hasil angket respon siswa:

Tabel 6. Tabel Hasil Angket Respon Siswa

\begin{tabular}{clcc}
\hline No. & & Aspek & Presentase \\
\hline 1 & Isi & $100 \%$ \\
2 & Penyajian & $95,6 \%$ \\
3 & Bahasa & $97,5 \%$ \\
4 & Grafis & $92,2 \%$ \\
5 & Kesesuaian dengan Pendekatan Kontekstual & $92,5 \%$ \\
\hline \multicolumn{3}{r}{ Rata-Rata Presentase } & $\mathbf{9 5 , 6 \%}$ \\
& & Penilaian Kategori & Sangat Baik \\
\hline
\end{tabular}

Sumber: diolah peneliti (2021)

Berdasarkan hasil tabel penghitungan angket respon siswa tersebut, rerata persentase yang didapatkan sebesar 95,6\% menunjukkan interpretasi sangat baik. Penelitian serupa juga dilaksanakan oleh (Pratama \& Sakti, 2020) bahwa rata-rata angket respon siswa mendapat hasil sebesar $91,8 \%$ meraih predikat sangat baik. Selaras dengan penelitian yang dilakukan oleh (Triani, 2019) hasil dari angket respon siswa memeproleh persentase sebesar 87,75\% dengan predikat sangat baik. Penelitian yang dilakukan oleh (Rahmawati \& Susanti, 2019) diperoleh hasil respon peserta didik dengan nilai $96,1 \%$ termasuk dalam kriteria sangat dipahami terhadap e-book yang dikembangkan.

\section{PEMBAHASAN}

Hasil rata-rata presentase validasi ahli materi pada bahan ajar ini memperoleh 85,2\% hal ini menunjukkan bahwa komponen kelayakan isi terdapat aspek cakupan materi yang cukup, materi yang sesuai dengan contoh nyata pada kehidupan maupun kegiatan sehari-hari. Pada komponen kelayakan materi juga terdapat ketersediaan soal latihan berbasis high thinking order skill dalam setiap bab dan kelengkapan materi yang sesuai dengan kompetensi dasar dan 


\section{Educatio: Jurnal IImu Kependidikan}

Vol. 16, NNo 1 Juli 2021, hal. 58-70

http://e-journal.hamzanwadi.ac.id/index.php/edc

e-ISSN: 2527-9998 DOI: 10.29408/edc.v16i1.3550

kompetensi inti. Sehingga berdasarkan hasil analisis validasi ahli materi tersebut, bahan ajar yang dikembangkan mendapatkan kelayakan dengan interpretasi kategori sangat layak dipergunakan dalam proses belajar mengajar.

Rata-rata presentase validasi ahli bahasa memperoleh skor 94,3\% hal ini menunjukkan bahwa bahasa dalam bahan ajar sudah sesuai terhadap perkembangan dan kondisi siswa. Terdapat kata motivasi pada bagian pendahuluan disetiap bab yang membangkitkan semangat siswa untuk belajar. Koherensi dan kerunturan alur berpikir yang sistematis dan kekonsistenan penggunaan istilah dan lambang memudahkan siswa dalam memahami materi dalam bahan ajar.

Hasil rata-rata presentase validasi ahli grafis mendapat skor $87,1 \%$ hal ini menunjukkan bahwa ilustrasi cover bahan ajar mampu mempresentasikan gambaran mengenai materi akuntansi persediaan. Ilustrasi, gambar dan video dapat memberikan kemudahan siswa dalam memahami materi akuntansi persediaan. Unsur tata letak dari awal hingga akhir dalam bahan ajar ditampilkan secara utuh untuk menyajikan materi akuntansi persediaan.

Rata-rata keseluruhan hasil validasi ahli mendapat skor 88,87\% sehingga bahan ajar yang telah dikembangkan mendapat predikat sangat layak dan bisa dipergunakan dan dimanfaatkan dalam menunjang kegiatan pembelajaran.

Hasil angket respon siswa mendapat presentase 95,6\% dengan interpretasi sangat baik. Hal ini mengindikasikan bahwa materi yang telah disajikan dalam bahan ajar sudah sesuai. Penyajian isi bahan ajar dapat dipahami oleh siswa, baik dari petunjuk penggunaan, peta konsep, ilustrasi, gambar, video hingga fitur yang disediakan. Bahasa dalam bahan ajar sudah sesuai dengan tingkatan usia siswa. Bahan ajar dikembangkan dengan pendekatan kontekstual membuat siswa lebih mudah memahami materi akuntansi persediaan.

\section{SIMPULAN}

Bahan ajar ini flip book kontekstual berbasis android materi Akuntansi Persediaan Kelas XI SMK Akuntansi Keuangan dan Lembaga telah berhasil disusun dan dikembangkan menggunakan model pengembangan 4D tanpa tahap penyebaran. Kelayakan bahan ajar yang telah dikembangkan didapatkan hasil analisis berupa persentase dari empat validator ahli dapat diambil kesimpulan bahwa bahan ajar terbukti valid dan termasuk dalam kategori sangat layak dimanfaatkan pada kegiatan pembelajaran. Respon siswa terhadap bahan ajar flip book kontekstual berbasis android ini memperoleh hasil respon dengan kriteria interpretasi sangat baik dan bisa dimanfaatkan pada kegiatan pembelajaran sebagai sumber belajar.

\section{UCAPAN TERIMA KASIH}

Penelitian dengan judul "Pengembangan Bahan Ajar Flip Book Kontekstual Berbasis Android Pada Materi Akuntansi Persediaan Kelas XI AKL SMKN 1 Geger Kab.Madiun" atas bantuan dan dukungan yang telah diberikan banyak pihak diucapkan terima kasih. Khususnya 
kepada program studi Pendidikan Akuntansi, Universitas Negeri Surabaya dan SMKN 1 Geger Kab.Madiun.

\section{DAFTAR PUSTAKA}

Aini, E. N., \& Susanti. (2019). Pengembangan Bahan Ajar Berbasis Kontekstual Mata Pelajaran Akuntansi dan Keuangan Lembaga. Jurnal Pendidikan Akuntansi, 7(3), 331-335.

Alawiyah, M., \& Susanti. (2019). Pengembangan Bahan Ajar Berbasis Kontekstual Pada Mata Pelajaran SMK Kompetensi Keahlian Perbankan Dan Keuangan Mikro. Jurnal Pendidikan Akuntansi (JPAK), 7(3), 422-428.

Andani, D. T., \& Yulian, M. (2018). Pengembangan Bahan Ajar Electronic Book Menggunakan Software Kvisoft Flipbook Pada Materi Hukum Dasar Kimia di SMA Negeri 1 Panton Reu Aceh Barat. Jurnal IPA \& Pembelajaran IPA, 2(1), 1-6. https://doi.org/10.24815/jipi.v2i1.10730

Andriani, M., Muhali, M., \& Dewi, C. A. (2019). Pengembangan Modul Kimia Berbasis Kontekstual Untuk Membangun Pemahaman Konsep Siswa Pada Materi Asam Basa. Hydrogen: Jurnal Kependidikan Kimia, 7(1), 25. https://doi.org/10.33394/hjkk.v7i1.1653

Anisa, C. A., \& Rohayati, S. (2019). Pengembangan Bahan Ajar Perbankan Dasar Berbasis Kontekstual Pada Materi Kredit Perbankan Kelas X Akuntansi Di Smk Negeri Mojoagung. Jurnal Pendidikan Akuntansi (JPAK), 7(1).

Asrowi, Hadaya, A., \& Hanif, M. (2019). The impact of using the interactive e-book on students' learning outcomes. International Journal of Instruction, 12(2), 709-722. https://doi.org/10.29333/iji.2019.12245a

Astuti, S. P., Kartini, T., \& Djaja, S. (2018). Pengembangan Modul Mata Pelaaran Akuntansi Keuangan Kompetensi Dasar Persediaan Barang Dagangan Pada Siswa Kelas Xi Akuntansi Di Smk Negeri 1 Jember Semester Genap Tahun Ajaran 2017/2018. JURNAL PENDIDIKAN EKONOMI: Jurnal Ilmiah Ilmu Pendidikan, Ilmu Ekonomi Dan Ilmu Sosial, 12(1), 51. https://doi.org/10.19184/jpe.v12i1.7473

Besthari, N. F. I. (2017). Pengembangan Quick Learn Myob ( QLM ) Berbasis Android Sebagai Bahan Ajar Pendukung Mata Pelajaran Komputer Akuntansi Perusahaan Jasa Kelas XI Akuntansi SMK Negeri 1 Jombang. Jurnal Pendidikan Akuntansi, 155-159.

Bhabiet, L., Accraf, R., Khery, Y., Kimia, P. P., Mataram, I., \& No, J. P. (2018). Pengembangan E-Modul Interaktif Berbasis Android dan Nature Of Science Pada Materi Ikatan Kimia dan Gaya Antar Molekul Untuk Menumbuhkan Literasi Sains Siswa. Hydrogen: Jurnal Kependidikan Kimia, 6(2), 133-141.

Böhm, S., \& Constantine, G. P. (2016). Impact of contextuality on mobile learning acceptance: An empirical study based on a language learning app. Interactive Technology and Smart Education, 13(2), 107-122. https://doi.org/10.1108/ITSE-02-2016-0003

Fitriyani, A. V., \& Susanti. (2020). Bahan Ajar E-Book Interaktif Mata Pelajaran Praktikum Akuntansi Lembaga Berbasis Kontekstual. Jurnal Penelitian Dan Pengembangan ..., 4, 514-525.

Retrieved

from https://ejournal.undiksha.ac.id/index.php/JJL/article/view/29740

Fitryani, H., \& Hunaepi. (2016). Pengembangan Modul Elektronik Berbasis Smartphone Berplatform Android Pada Mata Kuliah Taksonomi Tumbuhan Tinggi. Jurnal Ilmiah 


\section{Educatio: Jurnal IImu Kependidikan}

Vol. 16, No 1 Jufi 2021, hal. 58-7o

http://e-journal.hamzanwadi.ac.id/index.php/edc

e-ISSN: 2527-9998 DOI: 10.29408/edc.v16i1.3550

Biologi “Bioscientist," 4(2), 97-106.

Laili, Y. N., \& Rohayati, S. (2018). Pengembangan Bahan Ajar Elektronik Berbasis Android Dengan Pendekatan Saintifik pada Mata Pelajaran Perbankan Dasar di SMK Negeri 2 Kediri. Jurnal Pendidikan Akuntansi (JPAK), 6(3).

Logan, R. M., Johnson, C. E., \& Worsham, J. W. (2020). Development of an e-learning module to facilitate student learning and outcomes. Teaching and Learning in Nursing, 000, 7-10. https://doi.org/10.1016/j.teln.2020.10.007

Ningsih, I. D. M., \& Hakim, L. (2020). Pengembangan Buku Kontekstual Mata Pelajaran Layanan Lembaga Keuangan Syariah. Jurnal Penelitian Dan Pengembangan Pendidikan, 4(2), 278. https://doi.org/10.23887/jppp.v4i2.26170

Nurfita, R., \& Susanti. (2018). Pengembangan Bahan Ajar Akuntansi Keuangan Berbasis Kontekstual Pada Materi Rekonsiliasi Bank Kelas XI Akuntansi SMK Negeri Di Surabaya. Jurnal Pendidikan Akuntansi (JPAK), 6(3), 308-314. Retrieved from jurnalmahasiswa.unesa.ac.id/index.php/jpak/article/view/26129

Oktaviana, P., \& Susilowibowo, J. (2017). Pengembangan Handout Berbasis Android Sebagai Pendukung Bahan Ajar untuk Mata Pelajaran Akuntansi Materi Akuntansi Persediaan di Kelas XI Akuntansi SMK Negeri 2 Tuban. Jurnal Pendidikan Akuntansi, 2.

Permendikbud. Nomor 8 Tahun 2016 tentang Buku yang Digunakan oleh Satuan Pendidikan., (2016). Jakarta: Kemendikbud.

Prasetyo, M. B. (2018). Pengembangan Bahan Ajar Mobile Learning Spreadsheet Berbasis Android pada Materi Siklus Akuntansi Perusahaan Jasa untuk Kelas X Akuntansi SMK Negeri 2 Buduran Sidoarjo. Jurnal Pendidikan Akuntansi, 6(2), 172-176.

Prastowo, A. (2018). Sumber Belajar dan Pusat Sumber Belajar Teori dan Aplikasinya di Sekolah/Madrasah. Depok: Prenadamedia Group.

Pratama, D. P. A., \& Sakti, N. C. (2020). Pengembangan Media Pembelajaran Handout Digital Berbasis Android Pada Materi APBN dan APBD Kelas XI IPS. Jurnal Pendidikan Ekonomi Undiksha, 1(1), 43-53.

Putra, N. S., \& Rochmawati, R. (2020). Pengembangan Bahan Ajar Mata Pelajaran Akuntansi Perbankan Dan Keuangan Mikro Berbasis Contextual Teaching and Learning (Ctl). Edunomic Jurnal Pendidikan Ekonomi, 8(2), 61. https://doi.org/10.33603/ejpe.v8i2.3677

Rahmawati, S., \& Susanti. (2019). Pengembangan Bahan Ajar E-Book Pada Mata Pelajaran Praktikum Akuntansi Lembaga Berbasis Kontekstual Untuk SMK. Jurnal Pendidikan Akuntansi, 7(3), 383-391.

Riduwan. (2016). Skala Pengukuran Variabel-Variabel Penelitian. Bandung: Alfabeta.

Royani, L., \& Susanti. (2019). Pengembangan Bahan Aajar Praktikum Akuntansi Lembaga Berbasis Contextual Teaching And Learning (CTL) Sebagai Pendukung Pembelajaran Kurikulum 2013 di SMK. Jurnal Pendidikan Akuntansi (JPAK), 7(2), 173-181.

Sakibayev, S., Sakibayev, R., \& Sakibayeva, B. (2019). The educational impact of using mobile technology in a database course in college. Interactive Technology and Smart Education, 16(4), 363-380. https://doi.org/10.1108/ITSE-12-2018-0103

Salma, D. K., \& Susanti. (2021). Pengembangan Bahan Ajar Berbasis Kontekstual Berbantu QR Code Pada Mata Pelajaran Praktikum Akuntansi Lembaga / Instansi Pemerintah Kelas XII SMK. 15, 1-8. https://doi.org/10.19184/jpe.v15i1.20213 


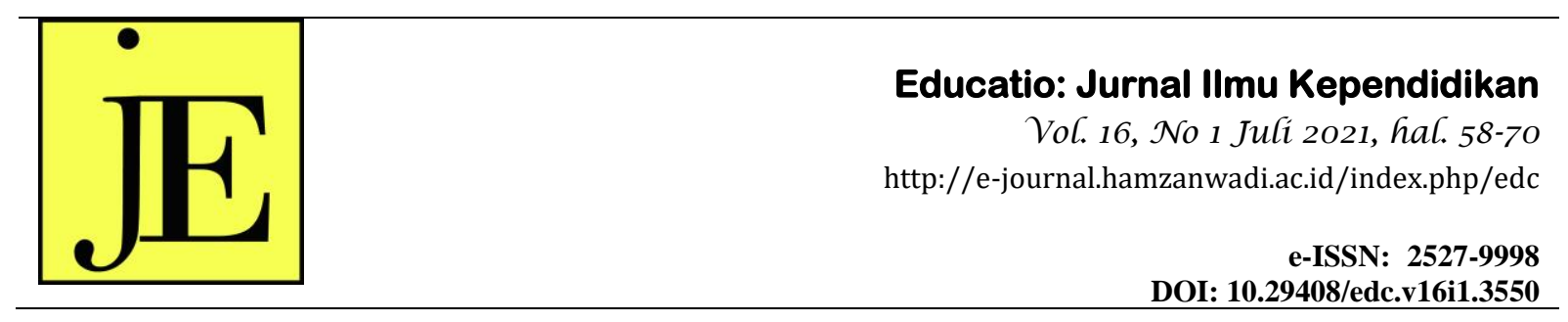

Sriwahyuni, I., Risdianto, E., \& Johan, H. (2019). Pengembangan Bahan Ajar Elektronik Menggunakan Flip Pdf Professional Pada Materi Alat-Alat Optik Di Sma. Jurnal Kumparan Fisika, 2(3), 145-152. https://doi.org/10.33369/jkf.2.3.145-152

Sugiyono. (2018). Metode Penelitian Kuantitatif, Kualitatif, dan R\&D. Bandung: Alfabeta.

Sumaeny, R. N., \& Susanti. (2018). Pengembangan Bahan Ajar Akuntansi Perbankan Berbasis Kontekstual Sebagai Pendukung Implementasi Kurikulum 2013 Pada Materi Komitmen Dan Kontijensi Kelas Xi Perbankan Di Smk Negeri 10 Surabaya. Jurnal Pendidikan Akuntansi (JPAK), 6(3).

Sung, H. Y., Hwang, G. J., Chen, C. Y., \& Liu, W. X. (2019). A contextual learning model for developing interactive e-books to improve students' performances of learning the Analects of Confucius. Interactive Learning Environments, O(0), 1-14. https://doi.org/10.1080/10494820.2019.1664595

Triani, D. A. (2019). Pengembangan Bahan Ajar Matematika Dengan Pendekatan Kontekstual Untuk Meningkatkan Hasil Belajar Siswa. Journal Focus Action Of Research Mathematic (Factor M), 2(1), 51-65.

Yulaika, N. F., Harti, \& Sakti, N. C. (2020). Pengembangan bahan ajar elektronik berbasis flip book untuk meningkatkan hasil belajar peserta didik. Jurnal Pendidikan Ekonomi, Manajemen Dan Keuangan, 4(1), 67-76. https://doi.org/10.26740/jpeka.v4n1.p67-76 